\title{
PENINGKATAN KEMAMPUAN KOMUNIKASI MATEMATIKA ANTARA SISWA YANG DIAJAR MENGGUNAKAN MODEL KOOPERATIF TIPE THINK PAIR SHARE (TPS) DENGAN TEAMS GAMES TOURNAMENT (TGT)
}

\author{
Minta Ito Simamora ${ }^{1}$, Yumira Simamora ${ }^{2}$ \\ Universitas Al Washliyah (UNIVA) Medan, Jalan Sisingamangaraja No. 10 Km. 5,5 Medan ${ }^{1,2}$ \\ email: mintaito.simamora@gmail.com
}

\begin{abstract}
ABSTRAK
Latar belakang masalah dalam penelitian ini adalah : (1) siswa masih kesulitan menyatakan ide matematika dengan berbicara, menulis, demonstrasi dan mengambar dalam bentuk visual, (2) siswa masih kesulitan menggunakan kosa kata/bahasa, notasi dan struktur matematik untuk menyatakan ide, menggambarkan hubungan dan pembuatan model, (3) guru belum bervariasi menggunakan mode-model pembelajaran, cenderung teacher-centered. Adapun tujuan dalam penelitian ini adalah untuk mengetahui peningkatan kemampuan komunikasi matematika antara siswa yang diajar menggunakan model pembelajaran kooperatif tipe Think Pair Share (TPS) dengan Tipe Teams Games Tournament (TGT) Kelas VIII MTs Laboratorium IAIN SU Tahun Pelajaran 2019-2020. Metode yang digunakan dalam penelitian ini adalah metode eksperimen, yaitu cara atau teknik yang digunakan untuk mencari perbedaan perlakuan tertentu. Hasil penelitian menunjukkan bahwa nilai rata-rata pretest (tes awal) siswa kelas eksperimen 1 adalah 44,371 dan nilai rata-rata pretest siswa kelas eksperimen 2 adalah 44,571. Selanjutnya diperoleh nilai rata-rata postest siswa kelas eksperimen 1 adalah 72,200 atau terdapat peningkatan kemampuan komunikasi matematika siswa dengan rata-rata 27,829 \% dan nilai rata-rata postest siswa kelas eksperimen 2 adalah 65,829 atau terdapat peningkatan kemampuan komunikasi matematika siswa dengan rata-rata 21,258 \%. Berdasarkan hasil perhitungan uji hipotesis, diperoleh $t_{\text {hitung }}>t_{\text {tabel }}$ yaitu 2,782> 1.997 berarti ada peningkatan kemampuan komunikasi matematika siswa yang menggunakan model pembelajaran kooperatif tipe Think Pair Share (TPS) dengan siswa yang menggunakan tipe Teams Games Turnament (TGT) di Kelas VIII MTs Laboratorium IAIN SU Tahun Pelajaran 2019-2020.
\end{abstract}

\section{Kata kunci :}

Kemampuan Komunikasi; TGT; TPS

\section{ABSTRACT}

The background of the problems in this study are: (1) students still have difficulty expressing mathematical ideas by speaking, writing, demonstrating and drawing in visual form, (2) students still having difficulty using vocabulary / language, notation and mathematical structures to express ideas, describe relationship and modeling, (3) teachers have not varied in using learning models, tend to be teacher-centered. The purpose of this study was to determine the increase in mathematics communication skills between students taught using the Think Pair Share (TPS) cooperative learning model with the Teams Games Tournament (TGT) Type for Class VIII MTs Laboratory IAIN SU Academic Year 2019-2020. The method used in this research is an experimental method, namely the method or technique used to find certain differences in treatment. The results showed that the pretest mean score of experimental class 1 students was 44,371 and the pretest mean score of experimental class 2 students was 44,571. Furthermore, it was obtained that the posttest average score of the experimental class 1 students was 72,200 or there was an increase in the students 'mathematical communication skills with an average of $27.829 \%$ and the post-test average score of the experimental class 2 students was 65.829 or there was an increase in the students' mathematical communication skills with an average of $21.258 \%$. Based on the results of the calculation of the hypothesis test, obtained tcount $>$ ttable, namely 2.782> 1.997, which means that there is an increase in students' mathematical communication skills using the Think Pair Share (TPS) cooperative learning model with students using the Teams Games Tournament (TGT) type in Class VIII MTs Laboratory IAIN SU Academic Year 2019-2020.

Keywords :

Communication Skills; TGT ;TPS 


\section{PENDAHULUAN}

Pendidikan merupakan sebuah kata yang sangat familiar kita dengarkan di dalam hidup sehari-hari, sebab pendidikan merupakan kegiatan penting yang dilakukan oleh hampir semua orang dari lapisan masyarakat. Pendidikan sebagai sesuatu yang penting memang tidak terlepas dari banyaknya pendapat dan asumsi tentang arti dan definisi pendidikan yang sebenarnya.

Dalam dunia pendidikan, seorang manusia tidak terlepas dari satu sisi yang dikatakan dengan belajar. dan belajar itu sendiri merupakan dasar dalam dunia pendidikan tersebut. Dalam pembelajaran matematika, siswa sering dihadapkan pada suatu masalah yang rumit dan abstrak. Dalam pembelajaran matematika sangat dibutuhkan komunikasi matematika agar dapat memahami maksud dari permasalahan yang diberikan. Kemampuan komunikasi matematika merupakan kemampuan berpikir manusia tingkat tinggi (higher level thinking), yang dapat mendorong seseorang untuk senantiasa memandang setiap masalah secara kritis serta mencoba untuk menyelesaikannya secara kreatif.

Menurut Istarani (2012) terdapat banyak model pembelajaran, salah satunya adalah model pembelajaran kooperatif (coorperative learning). Model pembelajaran kooperatif merupakan bentuk pembelajaran dengan cara siswa belajar dengan bekerja dalam kelompokkelompok kecil secara kolaboratif yang anggotanya terdiri dari empat sampai enam orang struktur kelompok yang bersifat heterogen (Rusman, 2014). Pada pembelajaran kooperatif keberhasilan siswa tergantung pada keberhasilan setiap kelompok anggotanya. Untuk itu akan membuat siswa bersemangat untuk saling membantu untuk memberikan pemahaman kepada anggota kelompoknya, sehingga bisa di pastikan bahwa semua anggota kelompoknya menguasai materi yang sedang dipelajari.

Terdapat banyak tipe model pembelajaran kooperatif diantaranya model pembelajaran Think Pair Share (TPS) dan Teams Games Turnament (TGT). Think Pair Share (TPS) dan Teams Games Turnament (TGT) merupakan bentuk pembelajaran kooperatif yang paling tua dan paling banyak diteliti (Salvin,2009). Model pembelajaran kooperatif tipe Think Pair Share (TPS) adalah salah satu tipe atau model pembelajaran kooperatif yang mudah diterapkan, melibatkan aktivitas seluruh siswa tanpa harus ada perbedaan status. Menurut Arends (Trianto, 2009) menyatakan bahwa Think Pair Share merupakan suatu cara yang efektik untuk membuat variasi suasana pola diskusi kelas. Sedangkan model pembelajaran kooperatif tipe Teams Games Turnament (TGT) adalah model pembelajaran kooperatif tipe TGT menggunakan turnamen akademik, yakni menggunakan kuis-kuis dan skor kemajuan individu dimana siswa berlomba dari wakil kelompok mereka dengan anggota kelompok lain yang kinerja akademik sebelumnya setara seperti mereka. Tapi permasalahannya tidak ada yang bisa menjamin bahwa suatu model pembelajaran akan selalu berhasil untuk diterapkan pada semua peserta didik dan pada setiapa bahasan. Berdasarkan uraian di atas, tujuan penelitian ini adalah mengetahui peningkatan kemampuan komunikasi matematika siswa yang menggunakan model pembelajaran kooperatif tipe Think Pair Share (TPS) dengan siswa yang menggunakan tipe Teams Games Turnament (TGT).

\section{METODE PENELITIAN}

Adapun desain penelitian yang digunakan dalam penelitian ini adalah desain eksperimen. Eksperimen dilakukan dengan maksud untuk melihat akibat dari 


\section{$\pi$ (Phi)}

suatu perlakuan. Pada desain ini, kelas akan dibagi menjadi dua kelas, yaitu kelas menggunkan model pembelajaran kooperatif tipe Think Pair Share (TPS) dan kelas menggunkan model pembelajaran kooperatif tipe Teams Games Turnament (TGT) dengan menggunakan pretes dan postes.

Tabel 1. Desain Penelitian Pretest Posttest Control Group Design

\begin{tabular}{cccc}
\hline Kelompok & Pretest & $\begin{array}{c}\text { Perlakuan } \\
\text { (Treatment) }\end{array}$ & Postest \\
\hline $\mathrm{R}_{1}$ & $\mathrm{O}_{1}$ & $\mathrm{X}_{1}$ & $\mathrm{O}_{2}$ \\
$\mathrm{R}_{2}$ & $\mathrm{O}_{1}$ & $\mathrm{X}_{2}$ & $\mathrm{O}_{2}$ \\
\hline
\end{tabular}

*)Sumber data: Sudijono (2011)

Keterangan

$\mathrm{R}_{1}$ : Penggunaan model pembelajaran kooperatif tipe TPS

$\mathrm{R}_{2}$ :Penggunaan model pembelajaran kooperatif tipe TGT

$\mathrm{X}_{1}$ :Perlakuan dengan menggunakan model pembelajaran kooperatif tipe TPS

$\mathrm{X}_{2}$ :Perlakuan dengan menggunakan model pembelajaran kooperatif tipe TGT

$\mathrm{O}_{1} \quad$ :Pretes

$\mathrm{O}_{2}$ :Postes

\section{Data dan Teknik Pengumpulan Data Data}

Data penelitian ini merupakan data kuantitatif berupa angka /pretes dan postes dari penelitian eksperimen penggunaan model pembelajaran kooperatif tipe Think Pair Share (TPS) dengan model pembelajaran kooperatif tipe Teams Games Turnament (TGT) pada kemampuan Komunikasi matematika.

\section{Teknik Pengumpulan Data}

Pengumpulan data yang digunakan pada penelitian ini adalah tes. Tes digunakan untuk mengukur kemampuan analisis komunikasi matematika dalam mempelajari materi lingkaran. Tes diberikan pada akhir (post-test) pembelajaran pokok bahasan bilangan bulat.

Sebelum perlakuan diberikan kedua kelompok eksperimen diberi pretest $\left(\mathrm{O}_{1}\right)$ untuk mengukur kondisi awal. Selanjutnya pada kelompok eksperimen-1 diberi perlakuan model pembelajaran kooperatif tipe Think Pair Share (TPS) $\left(\mathrm{X}_{1}\right)$, sedangkan pada kelompok eksperimen-2 diberi perlakuan model pembelajaran kooperatif tipe Teams Games Turnament (TGT) $\left(\mathrm{X}_{2}\right)$. Setelah selesai perlakuan kedua kelompok diberi posttest $\left(\mathrm{O}_{2}\right)$

\section{Instrumen Penelitian}

Instrumen penelitian adalah alat yang digunakan sebagai pengumpul data untuk memperoleh data yang diperlukan dalam suatu penelitian. Data yang dibutuhkan dalam suatu penelitian diperoleh dengan menggunakan instrumen yang tepat dan sesuai dengan kebutuhan penelitin. Instrumen yang digunakan dalam penelitian ini adalah tes, yaitu tes tentang lingkaran.

\section{Uji Validitas Data}

Sebelum tes digunakan maka terlebih dahulu harus diuji validitas dan realibitasnya.

\section{Uji Validitas Tes}

Uji validitas dilakukan untuk mengetahui apakah instrumen yang digunakan untuk memperoleh data sudah valid (sahih) atau belum. Pada penelitian ini uji validitas dilakukan dengan melakukan rumus korelaksi product moment dengan angka kasar sebagai berikut Sudijono, (2010) :

$$
r_{x y}=\frac{N \sum X Y-\left(\sum X\right)\left(\sum Y\right)}{\sqrt{\left\{N \sum X^{2}-\left(\sum X\right)^{2}\right\}\left\{N \sum Y^{2}-\left(\sum Y\right)^{2}\right\}}}
$$

Keterangan : 


\section{$\pi$ (Phi)}

\begin{tabular}{|c|c|}
\hline$r_{x y}$ & $\begin{array}{l}\text { :Angka indeks korelasi “ } r \text { ” } \\
\text { product moment }\end{array}$ \\
\hline $\mathrm{N}$ & : Jumlah siswa \\
\hline$\sum X$ & $\begin{array}{l}\text { :Variabel X } \\
\text { pertanyaan) }\end{array}$ \\
\hline & : Variabel Y ( Skor total) \\
\hline & $\begin{array}{l}\text { : Jumlah perkalian variab } \\
\mathrm{X} \text { dengan variabel Y }\end{array}$ \\
\hline
\end{tabular}

Harga $r_{x y}$ dikonsultasikan atau dibandingkan dengan harga kritis Product Moment dengan $\alpha=0.05$. Pengujian validitas dilakukan dengan membandingkan $r_{\text {hitung }}$ dengan $r_{\text {tabel }}$ product moment. Dengan kriteria jika $r_{\text {hitung }}>r_{\text {tabel }}$ maka butir soal tergolong valid.

\section{Uji Reliabilitas Tes}

Uji reliabilitas dilakukan untuk mengukur tingkat kepercayaan diri suatu instrumen. Suatu instrumen dinyatakan reliabel jika instrumen tersebut digunakan selalu memberikan hasil yang konsisten. Pada penelitian ini uji reliabilitas dilakukan dengan menggunakan rumus Alpha, yaitu :

$$
r_{11}=\left(\frac{n}{n-1}\right)\left(1-\frac{\sum s_{i}^{2}}{s_{t}^{2}}\right)
$$

Keterangan :

$$
\begin{array}{cl}
r_{11} & : \text { Koefisien reabilitas } \\
\mathrm{n} & \begin{array}{l}
\text { : Banyaknya item soal yang } \\
\text { dikeluarkan }
\end{array} \\
\sum s_{i}^{2} & \begin{array}{l}
\text { : Jumlah Varian sekor dari } \\
\text { tiap-tiap butir item }
\end{array} \\
s_{t}^{2} & : \text { Varian total }
\end{array}
$$

Untuk menafsirkan harga reliabilitas dari soal, maka harga tersebut dikonsultasikan atau dibandingkan dengan $\alpha=0.05$. Jika rumus $r_{\text {hitung }}>r_{\text {tabel }}$ maka tes tersebut dikatakan reliabel.

\section{Daya Pembeda}

Daya pembeda dari sebuah butir soal adalah kemampuan butir soal tersebut membedakan siswa yang mempunyai kemampuan tinggi, kemampuan sedang dengan siswa yang berkemampuan rendah.Tinggi atau rendahnya tingkat daya pembeda suatu butir soal dinyatakan dengan indeks daya pembeda (DP).

Untuk mengetahui daya pembeda dari butir sol tes digunakan rumus (Lestari. E. K, 2015) sebagai berikut :

Keterangan :

$$
D P=\frac{\bar{X}_{A-} \bar{X}_{B}}{S M I}
$$

DP : indeks daya pembeda butir soal

$\bar{X}_{\mathrm{A}}$ :rata-rata skor jawaban siswa kelompok atas

$\bar{X}_{\mathrm{B}}$ : rata-rata skor jawaban siswa kelompok bawah

SMI : Skor Maksimum Ideal yaitu skor maksimum yang akan diperoleh siswa jika menjawab butir soal tersebut dengan tepat (sempurna)

Kriteria yang digunakan untuk menginterpretasikan indeks daya pembeda disajikan pada tabel berikut:

Tabel 2. Kriteria Indeks Daya Pembeda Instrumen

\begin{tabular}{cc}
\hline Nilai & Interpretasi Daya \\
& Pembeda \\
\hline $\mathbf{0 , 7 0}<\boldsymbol{D P} \leq \mathbf{1 , 0 0}$ & Sangat Buruk \\
$\mathbf{0 , 4 0}<\boldsymbol{D P} \leq \mathbf{0 , 7 0}$ & Baik \\
$\mathbf{0 , 2 0}<\boldsymbol{D P} \leq \mathbf{0 , 4 0}$ & Cukup \\
$\mathbf{0 , 0 0}<\boldsymbol{I} \boldsymbol{K}<\mathbf{0 , 2 0}$ & Buruk \\
$\boldsymbol{D P} \leq \mathbf{0 , 0 0}$ & Sangat Buruk \\
\hline
\end{tabular}

*)Sumber data: Sudijono, (2011)

\section{Tingkat Kesukaran Soal}

Bermutu atau tidaknya butir-butir item pada instrument dapat diketahui dari derajat kesukaran atau taraf kesulitan yang dimiliki oleh masing-masing butir item tersebut. Indeks kesukaran adalah suatu bilangan yang menyatakan derajat kesukaran suatu butir soal.

Rumus yang digunakan untuk menentukan indeks kesukaran instrument tes tipe subjektif yaitu:

$$
I K=\frac{\bar{X}}{S M I}
$$


Keterangan :

$I K \quad$ : indeks kesukaran butir soal

$\bar{X} \quad$ : rata-rata jawaban siswa pada suatu butir soal

SMI : Skor Maksimum Ideal yaitu skor maksimum yang akan diperoleh siswa jika menjawab butir soal tersebut dengan tepat (sempurna)Indeks kesukaran suatu butir soal diinterpretasikan dalam kriteria sebagai berikut:

Tabel 3. Kriteria Indeks Kesukaran Instrumen

\begin{tabular}{cc}
\hline IK & $\begin{array}{c}\text { Interpretasi Indeks } \\
\text { Kesukaran }\end{array}$ \\
\hline $\boldsymbol{I} \boldsymbol{K}=\mathbf{0 , 0 0}$ & Terlalu Sukar \\
$\mathbf{0 , 0 0}<\boldsymbol{I} \boldsymbol{K} \leq \mathbf{0 , 3 0}$ & Sukar \\
$\mathbf{0 , 3 0}<\boldsymbol{I} \boldsymbol{K} \leq \mathbf{0 , 7 0}$ & Sedang \\
$\mathbf{0 , 7 0}<\boldsymbol{I} \boldsymbol{K}<\mathbf{1}, \mathbf{0 0}$ & Mudah \\
$\boldsymbol{I} \boldsymbol{K}=\mathbf{1 , 0 0}$ & Terlalu Mudah \\
\hline
\end{tabular}

*)Sumber data: Sudijono, (2011)

\section{Analisis Data}

Analisis data dilakukan setelah selesai mengumpulkan data penelitian dari para responden. Adapun langkah - langkah yang dilakukan dalam menganalisis penelitian ini adalah:

\section{Uji Normalitas}

Uji normalitas data yang dilakukan adalah untuk mengetahui apakah sampel yang digunakan berdistribusi normal atau tidak. Untuk menguji normalitas data dapat digunakan uji Lilliefors (Sudjana,2005) dengan langkah-langkah sebagai berikut:

a. Pengamatan $x_{1}, x_{2}, \ldots, x_{n}$ dijadikan bilangan baku $z_{1}, z_{2}, \ldots, z_{n}$ dengan menggunakan rumus $z_{i}=\frac{X_{i}-\bar{X}}{s}(\vec{x}$ dan $\mathrm{s}$ masing-masing merupakan rata-rata dan simpangan baku sampel).

b. Untuk tiap bilangan baku ini dan menggunakan daftar distribusi normal baku, kemudian dihitung peluang $\mathrm{F}\left(z_{i}\right)=\mathrm{P}\left(z \leq z_{i}\right)$.

c. Selanjutnya dihitung proporsi $z_{1}, z_{2}$, $\ldots, z_{n}$ yang lebih kecil atau sama dengan $z_{i}$. Jika proporsi ini dinyatakan oleh $\mathrm{S}\left(z_{i}\right)$, maka:

$$
\mathrm{S}\left(z_{i}\right)=\frac{\text { banyaknya } z_{1}, z_{2}, \ldots, z_{n} \text { yang } \leq z_{i}}{n}
$$

d. Hitung selisih $\mathrm{F}\left(z_{i}\right)-\mathrm{S}\left(z_{i}\right)$ kemudian tentukan harga mutlaknya.

e. Ambil harga yang paling besar di antara harga-harga mutlak selisih tersebut. Sebutlah harga terbesar ini $L_{0}$, untuk menerima atau menolak hipotesis nol, maka bandingkan $L_{0}$ dengan nilai kritis $L$ yang diambil dari daftar nilai kritis untuk taraf nyata $\square \square 5 \%$. Kriterianya adalah tolak hipotesis nol bahwa populasi berdistribusi normal jika $L_{0}$ yang diperoleh dari data perhitungan melebihi L dari tabel. Dalam hal lainnya hipotesis nol diterima.

\section{Uji Homogenitas}

Uji homogenitas dilakukan untuk memperoleh asumsi bahwa sempel penelitian berawal dari kondisi yang sama atau homogen. Untuk menguji apakah sampel-sampel yang diambil secara acak derasal dari populasi yang sama dilakukan uji Bartlett (Sudjana, 2005). Adapun langkah-langkah sebagai berikut:

a. Menentukan hipotesis

$$
\left\{\begin{array}{l}
H_{0}: \sigma_{1}^{2}=\sigma_{2}^{2}=\ldots=\sigma_{k}^{2} \\
H_{\mathrm{i}}: \text { Paling sedikit satu tanda sama } \\
\text { dengan tidak berlaku, berdasrkan } \\
\text { sampel-sampel acak yang masing- } \\
\text { masing diambil dari setiap populasi. }
\end{array}\right.
$$

b. Menghitung harga-harga yang perlu perlu untuk uji Bartlett.

$$
\begin{aligned}
& H_{0}: \sigma_{1}^{2}=\sigma_{2}^{2}=\ldots=\sigma_{k}^{2} \\
& \mathrm{H}_{0}: \sigma_{1}^{2}=\sigma_{2}^{2}=\ldots=\sigma_{k}^{2}
\end{aligned}
$$




\section{$\pi$ (Phi)}

Tabel 4. Harga-harga yang perlu untuk di uji Bartlett

\begin{tabular}{|c|c|c|c|c|c|}
\hline $\begin{array}{c}\text { Sampel } \\
\text { ke }\end{array}$ & $\overline{\mathrm{Dk}}$ & $\frac{1}{d k}$ & $s_{i}^{2}$ & $\overline{\log s_{i}^{2}}$ & $\begin{array}{c}(\mathrm{dk}) \\
\log s_{i}^{2}\end{array}$ \\
\hline 1 & $\mathrm{n}_{1-1}$ & $1 /\left(\mathrm{n}_{1-} 1\right)$ & \multirow{2}{*}{$S_{1}^{2}$} & \multirow{2}{*}{$\log S_{1}^{2}$} & $\left(\mathrm{n}_{1-} 1\right)$ \\
\hline 2 & $\mathrm{n}_{2}-$ & $1 /\left(\mathrm{n}_{2-1} 1\right)$ & & & $\log S^{2}$ \\
\hline . & 1 & & \multirow[t]{2}{*}{$S_{2}^{2}$} & \multirow[t]{2}{*}{$\log S_{2}^{2}$} & $\left(\mathrm{n}_{2}-\right.$ \\
\hline . & . & & & & 1) $\log$ \\
\hline \multirow[t]{4}{*}{ K } & . & $1 /\left(n_{k}-\right.$ & \multirow{2}{*}{$s_{k}^{2}$} & \multirow{2}{*}{$\log S_{k}^{2}$} & $S_{2}^{2}$ \\
\hline & $\begin{array}{c}\mathrm{n}_{\mathrm{k}}- \\
1\end{array}$ & 1) & & & \\
\hline & & & & & $\left(\mathrm{n}_{\mathrm{k}^{-}}\right.$ \\
\hline & & & & & 1) $\log S_{k}^{2}$ \\
\hline \multirow[t]{2}{*}{ Jumlah } & $\sum(\mathrm{n}$ & $\sum(1 /$ & \multirow[t]{2}{*}{-- } & \multirow[t]{2}{*}{ - } & $\sum\left(\mathrm{n}_{\mathrm{i}^{-}}\right.$ \\
\hline & $i-1)$ & $\left.n_{i}-1\right)$ & & & 1) $\log s_{i}^{2}$ \\
\hline
\end{tabular}

*)Sumber data: Sudijono, (2011)

c. Menghitung varians dari semua sampel dengan rumus:

$\left(\mathrm{S}^{2}\right)=\left(\sum\left(\mathrm{n}_{\mathrm{i}}-1\right) s_{i}^{2} / \sum\left(\mathrm{n}_{\mathrm{i}}-1\right)\right)$

d. Menentukan Harga Satuan B dengan rumus;

$\mathrm{B}=\left(\log \mathrm{S}^{2}\right) \sum\left(\mathrm{n}_{\mathrm{i}}-1\right)$

e. Menghitung harga chi-kuadrat dengan rumus :

$$
\chi^{2}=(\ln 10)\left\{B-\sum\left(n_{i}-1\right) \log s_{i}{ }^{2}\right\}
$$

dengan $\ln 10=2,3026$, disebut logaritma asli dari bilangan 10 . Dengan taraf nyata 0,05 kita tolak hipotesis $H_{0}$ jika $\chi^{2} \geq$

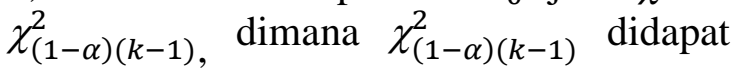
dari daftar distribusi chi-kuadrat dengan peluang $(1-\alpha)$ dan $d k=(k-1)$.

\section{Uji Hipotesis}

Setelah dilaksanakan pembelajaran menggunakan model pembelajaran kooperatif tipe TPS dan tipe TGT, maka diberikan tes menggunakan lembar tes untuk masing-masing model pembelajaran tersebut. Dengan tes tersebut didapatkan data kemampuan komunikasi matematika siswa. Data yang sudah mendapatkan kemudian disusun, lalu dilakukan uji hipotesis. Rumus uji t yang digunakan menurut Sugiyono (2011) yaitu:

$$
t=\frac{\overline{X_{1}}-\overline{X_{2}}}{\sqrt{\frac{s_{1}^{2}}{n_{1}}+\frac{s_{2}^{2}}{n_{2}}-2 r\left(\frac{s_{1}}{\sqrt{n_{1}}}\right)\left(\frac{s_{2}}{\sqrt{n_{2}}}\right)}}
$$

Keterangan :

$\underline{X}_{1}=$ Skor rata-rata nilai kelas TPS

$\bar{X}_{2}=$ Skor rata-rata nilai kelas TGT

$S_{1}^{2}=$ Varian pada kelas TPS

$S_{2}^{2}=$ Varian pada kelas TGT

$\mathrm{n}_{1}=$ Jumlah sampel kelas TPS

$\mathrm{n}_{2}=$ Jumlah sampel kelas TGT

$r \quad=$ Related (pasangan)

dengan $\alpha=0.05$ maka kriteria pengujian $\mathrm{H}_{\mathrm{o}}$ diterima jika $-t_{1-\frac{1}{2} a} \leq t \leq t_{1-\frac{1}{2} a}$, dimana $t_{1-\frac{1}{2} a}$ didapat dari daftar distribusi $\mathrm{t}$ dengan $\mathrm{dk}=\left(n_{1}+n_{2}-2\right)$ dan peluang $\left(1-\frac{1}{2} a\right)$ untuk harga-harga $\mathrm{t}$ lainnya $\mathrm{H}_{\mathrm{o}}$ ditolak.

Berdasarkan hipotesis penelitian maka uji hipotesis yang dilakukan adalah melihat Kemampuan komunikasi matematika menggunakan model pembelajaran kooperatif tipe TPS lebih tinggi atau lebih baik dibandingkan dengan model pembelajaran kooperatif tipe TGT secara signifikan maka, digunakan hipotesis statistik (Sudijono, 2011).

$$
\begin{array}{lll}
\mathrm{H}_{\mathrm{o}}: \rho_{1}=\rho_{2} & \text { (tidak beda) } \\
\mathrm{H}_{\mathrm{a}}: \rho_{1} \neq \rho_{2} & \text { (berbeda) }
\end{array}
$$

\section{HASIL DAN PEMBAHASAN \\ Hasil Penelitian}

Nilai Kemampuan Komunikasi Matematika Pretest Kelas Eksperimen 1 dan Kelas Eksperimen 2

Penelitian ini dilakukan di MTs Laboratorium IAIN SU dengan mengambil sampel dari dua kelas. Dimana terpilih siswa kelas VIII-1 sebagai kelas Eksperimen 1 dan siswa kelas VIII-2 sebagai kelas Eksperimen 2. Kelas Eksperimen 1 dan kelas Eksperimen 2 masing-masing berjumlah 35 orang. Jadi 


\section{$\pi$ (Phi)}

jumlah total sampel semuanya adalah 70 orang.

Untuk mengetahui kemampuan awal siswa tanpa dipengaruhi model pembelajaran siswa diberi tes awal (pretest). Berikut disajikan hasil analisis data penelitian pretest kemampuan komunikasi matematika siswa.

Tabel 5. Data Kemampuan Komunikasi Matematika Pretest Kelas Eksperimen 1 dan Kelas Eksperimen 2

\begin{tabular}{clcc}
\hline No & Statistik & $\begin{array}{c}\text { Kelas } \\
\text { Eksperimen } \\
1\end{array}$ & $\begin{array}{c}\text { Kelas } \\
\text { Eksperimen } \\
2\end{array}$ \\
\hline 1 & N & 35 & 35 \\
2 & Jumlah & 1553 & 1560 \\
& Nilai & & \\
3 & Rata-rata & 44,371 & 44,571 \\
4 & Simpangan & 9,530 & 9,082 \\
& Baku & & \\
5 & Varians & 90,829 & 82,487 \\
\hline
\end{tabular}

*)Sumber data: Perhitungan statistik

Dari tabel diatas diperoleh nilai ratarata pretest siswa kelas Eksperimen 1 adalah 44,371 sedangkan nilai rata-rata pretest siswa kelas Eksperimen 2 adalah 44,571. Untuk simpangan baku dan varians kelas Eksperimen 1 sebesar 9,530 dan 90,829 sedangkan simpangan baku dan varians kelas Eksperimen 2 sebesar 9,082 dan 82,487. Ternyata dari pengujian nilai pretest kelas Eksperimen 1 dan kelas Eksperimen 2 memiliki kemampuan awal kedua sampel terdapat perbedaan sedikit saja. Data diatas dapat disajikan dalam bentuk diagram batang di bawah ini.

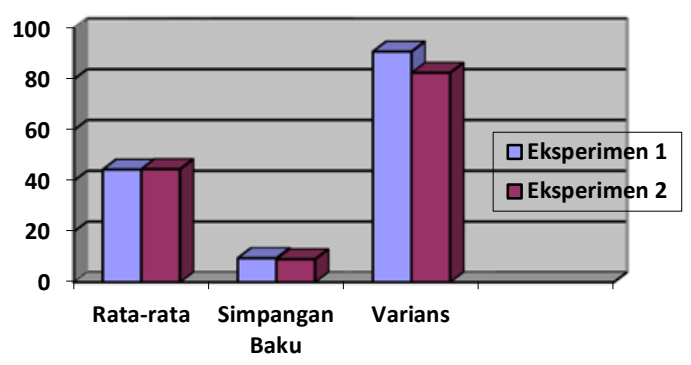

Gambar 4.1 Data Kemampuan Komunikasi Matematika Pretest Kelas Eksperimen 1 dan Kelas Eksperimen 2
Jurnal Pendidikan Matematika

Volume 4 Nomor 2 Tahun 2020

\section{Nilai Kemampuan Komunikasi Matematika Postest Kelas Eksperimen 1 dan Kelas Eksperimen 2}

Setelah diketahui kemampuan awal, kemudian dilakukan pembelajaran dengan menggunakan dua model pembelajaran yang berbeda pada kedua kelas. Kelas Eksperimen 1 kelas VIII-1 dengan menggunakan model pembelajaran Kooperatif tipe Think Pair Share (TPS) dan kelas Eksperimen 2 kelas VIII-2 dengan model pembelajaran Teams Games Tournament (TGT). Pada akhir pertemuan, siswa kembali diberikan postest. Tujuan diberikan postest adalah untuk mengetahui peningkatan kemampuan komunikasi matematika siswa dalam menyelesaikan soal matematika. Berikut disajikan hasil analisis data penelitian postest kemampuan komunikasi matematika siswa.

Tabel 6. Data Kemampuan Komunikasi Matematika Postest Kelas Eksperimen 1 dan Kelas Eksperimen 2

\begin{tabular}{clcc}
\hline \multirow{2}{*}{ No } & \multirow{2}{*}{ Statistik } & $\begin{array}{c}\text { Eksperimen } \\
\mathbf{1}\end{array}$ & $\begin{array}{c}\text { Eksperimen } \\
\mathbf{2}\end{array}$ \\
\hline 1 & N & 35 & 35 \\
2 & Jumlah & 2527 & 2304 \\
3 & Rata-rata & 72,200 & 65,829 \\
4 & Simp. Baku & 10,079 & 9,080 \\
5 & Varians & 101,579 & 82,440 \\
\hline
\end{tabular}

*)Sumber data: Perhitungan statistik

Dari hasil pemberian postest diperoleh nilai rata-rata postest siswa kelas Eksperimen 1 adalah 72,200 sedangkan nilai rata-rata postest siswa kelas Eksperimen 2 adalah 65,829. Untuk simpangan baku dan varians kelas Eksperimen 1 sebesar 10,079 dan 101,579 sedangkan simpangan baku dan varians kelas Eksperimen 2 sebesar 9,080 dan 82,440. Sehingga dapat disimpulkan bahwa rata-rata kemampuan komunikasi matematika siswa di kedua kelas Eksperimen 1 dan kelas Eksperimen 2 memiliki perbedaan, dapat dilihat dari diagram berikut ini 


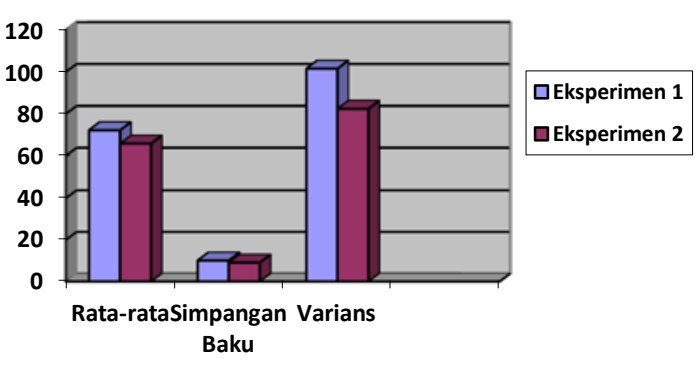

Gambar 4.2 Data Kemampuan Komunikasi Matematika Postest Kelas Eksperimen 1 dan Kelas Eksperimen 2

\section{Gain Ternormalisasi}

Untuk melihat perbedaan peningkatan kemampuan siswa dalam komunikasi matematika sebelum dan sesudah diberikan perlakuan pada kedua kelas secara keseluruhan, maka dilakukan analisis skor pretest dan postest yang rataratanya kemudian diperoleh rata-rata gain ternormalisasinya yang dapat dilihat pada tabel dibawah ini :

Tabel 7. Indeks Gain Kelas Eksperimen 1 dan Kelas Eksperimen 2

\begin{tabular}{cccccc}
\hline Kelas & $\begin{array}{c}\text { Prete } \\
\text { st }\end{array}$ & $\begin{array}{c}\text { Poste } \\
\text { st }\end{array}$ & Gain & $<\mathrm{g}>$ & $\begin{array}{c}\text { Katego } \\
\text { ri }\end{array}$ \\
\hline Eksp. 1 & 44,37 & 72,20 & 27,83 & 1,001 & Tinggi \\
Eksp. 2 & 44,57 & 65,83 & 21,26 & 0,622 & Sedang \\
\hline *)Sumber data: Perhitungan statistik & &
\end{tabular}

Berdasarkan tabel diatas dapat diketahui bahwa terdapat perubahan skor gain berturut-turut pada kelas Eksperimen 1 dan kelas Eksperimen 2 adalah sebesar 27,829 dan 21,258. Hal ini menunjukkan bahwa terdapat peningkatan skor rata-rata siswa dari sebelum dan setelah diberikan perlakuan pada kedua kelas. Rata-rata gain ternormalisasi $<$ g $>$ berturut-turut pada kelas Eksperimen 1 dan kelas Eksperimen 2 adalah 1,001 termasuk dalam kategori tinggi dan 0,622 termasuk dalam kategori sedang. Dengan demikian dapat dikatakan bahwa model pembelajaran Think Pair Share (TPS) lebih baik dalam meningkatkan kemampuan komunikasi matematika dibandingkan dengan model pembelajaran Teams Games Tournament (TGT).

Untuk mengetahui signifikan kesimpulan diatas perlu dilakukan perhitungan pengujian statistik. Untuk menguji peningkatan rata-rata kedua kelas dilakukan pengujian hipotesis dengan uji $t$, deskripsi analisisnya disajikan pada subbab berikut ini.

\section{Analisis Data Penelitian Uji Normalitas}

Untuk menguji normalitas data digunakan uji Liliefors yang bertujuan untuk mengetahui apakah data hasil penelitian memiliki selebaran data yang terdistribusi normal atau tidak. Sampel terdistribusi normal jika dipenuhi $L_{0}<L_{\text {tabel }}$ pada taraf signifikan $\alpha=0,05$. Secara ringkas hasil perhitungan data-data hasil penelitian diperlihatkan pada tabel berikut ini:

Tabel 8. Ringkasan Data Kemampuan Komunikasi Matematika Siswa dengan Uji Normalitas Data

\begin{tabular}{ccccccc}
\hline Kelas & \multicolumn{3}{c}{ Pretest } & \multicolumn{3}{c}{ Postest } \\
\cline { 2 - 7 } & $L_{\text {hitur }}$ & $L_{\text {tabe }}$ & $\begin{array}{c}\text { Keter } \\
\text { angan }\end{array}$ & $L_{\text {hitur }}$ & $L_{\text {tabe }}$ & $\begin{array}{c}\text { Keter } \\
\text { angan }\end{array}$ \\
Ekspe & 0,1 & 0,1 & Norm & 0,1 & 0,1 & Norm \\
rimen & 200 & 498 & al & 329 & 498 & al \\
1 & & & & & & \\
\hline
\end{tabular}

*)Sumber data: Perhitungan statistik

Uji normalitas data pretest kelas Eksperimen 1 (Model Pembelajaran Think Pair Share (TPS) diperoleh $L_{0}(0,1200)$ $<L_{\text {tabel }}(0,1498)$ dan data pretest kelas Eksperimen 2 (Model Pembelajaran Teams Games Tournament (TGT)) diperoleh $L_{0}$ $(0,1279)<L_{\text {tabel }}(0,1498)$. Data postest kelas Eksperimen 1 (Model Pembelajaran Think Pair Share (TPS) diperoleh $L_{0}$ $(0,1329)<L_{\text {tabel }}(0,1498)$ dan data pretest kelas Eksperimen 2 (Model Pembelajaran Teams Games Tournament (TGT)) diperoleh $L_{0}(0,1456)<L_{\text {tabel }}(0,1498)$. Dengan demikian dapat disimpulkan data 


\section{$\pi$ (Phi)}

pretest dan postest memiliki sebaran data yang terdistribusi normal.

\section{Uji Homogenitas}

Pengujian homogenitas data untuk mengetahui apakah sampel yang digunakan dalam penelitian berasal dari populasi yang homogen atau tidak, artinya apakah sampel yang dipilih dapat mewakili seluruh populasi yang ada.

Untuk pengujian homogenitas digunakan uji kesamaan kedua varians yaitu uji F. Jika $F_{\text {hitung }} \geq F_{\text {tabel }}$ maka $H_{O}$ ditolak dan jika $F_{\text {hitung }}<F_{\text {tabel }}$ maka $H_{O}$ diterima. Dengan derajat kebebasan pembilang $=\left(n_{1}-1\right)$ dan derajat kebebasan penyebut $=\left(n_{2}-1\right)$ dengan taraf nyata $\alpha=0,05$. Ringkasan hasil perhitungan uji homogenitas disajikan pada tabel berikut :

Tabel 9. Data Kemampuan Komunikasi Matematika Siswa dengan Uji Homogenitas

\begin{tabular}{cccccc}
\hline Data & $\begin{array}{c}\text { Varians } \\
\text { Terbesar }\end{array}$ & $\begin{array}{c}\text { Varians } \\
\text { Terkecil }\end{array}$ & $\boldsymbol{F}_{\text {hitun }}$ & $\boldsymbol{F}_{\text {tabe }}$ & $\begin{array}{c}\text { Keteran } \\
\text { gan }\end{array}$ \\
\hline Pretes & 90,83 & 82,487 & 1,10 & 1,78 & Homog \\
$t$ & & & 1 & 6 & en \\
$\begin{array}{c}t \\
\text { Postes }\end{array}$ & 101,58 & 82,440 & 1,22 & 1,78 & Homog \\
$t$ & & & 7 & 6 & en \\
\hline
\end{tabular}

*)Sumber data: Perhitungan statistik

Dari tabel di atas diperoleh uji homogenitas pretest kelas Eksperimen 1 dan kelas Eksperimen 2 diperoleh $F_{\text {hitung }}(1,101)<F_{\text {tabel }}(1,786)$ dan data postest kelas Eksperimen 1 dan kelas Eksperimen 2 diperoleh $F_{\text {hitung }}(1,227)<$ $F_{\text {tabel }}(1,786)$. Dengan demikian dapat disimpulkan pretest dan postest kelas Eksperimen 1 dan kelas Eksperimen 2 homogen.

\section{Pengujian Hipotesis}

Setelah diketahui bahwa data kedua kelompok siswa terdistribusi normal, varian homogen, dan jumlah sampel Eksperimen 1 dan Eksperimen 2 sama, selanjutnya dilakukan pengujian hipotesis.
Pengujian hipotesis dilakukan pada data postest dan diuji menggunakan uji-t dua pihak dengan cara membandingkan ratarata postest antara siswa yang diajarkan dengan model pembelajaran Think Pair Share (TPS) dan siswa yang diajarkan dengan model pembelajaran Teams Games Tournament (TGT). Hasil pengujian pada taraf signifikan $\alpha=0,05$ dan $\mathrm{dk}=n_{1}+$ $n_{2}-2=68 \quad$ dengan $t_{\text {hitung }}=2,782$ dan $t_{\text {tabel }}=1,997$ sehingga diperoleh $t_{\text {hitung }} 2,782>$ $t_{\text {tabel }} 1,997$. Maka adanya perbedaan peningkatan kemampuan komunikasi matematika komunikasi matematika antara siswa yang diajar menggunakan model kooperatif tipe Think Pair Share (TPS) dengan Teams Games Tournament (TGT) kelas VIII MTs Laboratorium IAIN SU Medan.

\section{Pembahasan}

Beradasarkan hasil penelitian yang telah dianalisis menunjukkan bahwa peningkatan kemampuan komunikasi matematika siswa yang mendapatkan model pembelajaran Think Pair Share (TPS) lebih baik dibandingkan dengan model pembelajaran Teams Games Tournament (TGT).

Sebelum diberikan model pembelajaran yang berbeda kepada masing-masing kelas terlebih dahulu dilakukan pretest agar peneliti mengetahui kemampuan awal siswa dalam kemampuan komunikasi matematika. Dari hasil penelitian diperoleh nilai rata-rata pretest (tes awal) siswa kelas Eksperimen 1 adalah 44,371 dan nilai rata-rata pretest siswa kelas Eksperimen 2 adalah 44,571.

Karakteristik kedua model pembelajaran yang diteliti berbeda, maka akan menghasilkan peningkatan kemampuan komunikasi yang berbeda pula. Perbedaan model pembelajaran kooperatif tipe Think Pair Share (TPS) yang paling mendasar adalah dalam 
langkah-langkah pembelajaran dimana guru memberi materi pelajaran kemudian memberikan siswa kesempatan kepada siswa untuk mempelajari materi secara berdiskusi kelompok, sedangkan pada model pembelajaran Teams Games Tournament (TGT) adalah pembelajaran menggunakan turnamen akademik, yakni menggunakan kuis-kuis dan skor kemajuan individu dimana siswa berlomba sebagai wakil dari kelompok mereka dengan anggota kelompok lain yang kinerja akademik sebelumnya setara seperti mereka

Setelah semua materi selesai diajarkan, siswa diberikan postest (tes akhir) untuk mengetahui bagaimana kemampuan komunikasi matematika siswa pada kedua kelas setelah dilakukan pembelajaran. Dari hasil penelitian diperoleh nilai rata-rata postest siswa kelas Eksperimen 1 adalah 72,200 atau terdapat peningkatan kemampuan komunikasi matematika siswa dengan ratarata $27,829 \%$ dan nilai rata-rata postest siswa kelas Eksperimen 2 adalah 65,829 atau terdapat peningkatan kemampuan komunikasi matematika siswa dengan ratarata $21,258 \%$.

Dari nilai rata-rata pretest dan postest dapat diketahui bahwa terdapat perubahan skor gain berturut-turut pada kelas Eksperimen 1 dan kelas Eksperimen 2 adalah sebesar 27,829 dan 21,258. Hal ini menuujukkan bahwa terdapat peningkatan skor rata-rata siswa dari sebelum dan setelah diberikan perlakuan pada kedua kelas. Rata-rata gain ternormalisasi $<\mathrm{g}>$ berturut-turut pada kelas Eksperimen 1 dan kelas Eksperimen 2 adalah 1,001 termasuk dalam kategori tinggi dan 0,622 termasuk dalam kategori sedang. Dengan demikian dapat dikatakan bahwa model pembelajaran kooperatif tipe Think Pair Share (TPS) lebih baik dalam meningkatkan kemampuan komunikasi matematika siswa dibandingkan dengan model pembelajaran Teams Games Tournament (TGT).

Dari hasil dari uji normalitas pretest menunjukan hasil pada kelas Eksperimen 1, diperoleh $L_{\text {tabel }}=0,1498$. Dengan taraf signifikan $\alpha=0,05$ dan $\mathrm{n}=35$, maka dari tabel diperoleh $L_{\text {hitung }}=0,1200$. Dengan demikian $L_{\text {hitung }}<L_{\text {tabel }}$, hingga dapat disimpulkan bahwa data skor pretest siswa yang menggunakan model pembelajaran Think Pair Share (TPS) berasal dari populasi yang berdistribusi normal.

Selanjutnya hasil dari uji normalitas postest kelompok Eksperimen 2 diperoleh $L_{\text {hitung }}=0,1456$. Dengan taraf signifikan $\alpha=0,05$ dan $\mathrm{n}=35$, maka dari tabel diperoleh $\quad L_{\text {tabel }}=0,1498$. Dengan demikian $L_{\text {hitung }}<L_{\text {tabel }}$, hingga dapat disimpulkan bahwa data skor postest siswa yang menggunakan model pembelajaran Teams Games Tournament (TGT) berasal dari populasi yang berdistribusi normal.

Berikunya hasil dari uji homogenitas pretest dan posttest adalah homogen, dan dari perhitungan didapat $F_{\text {hitung }}($ pretest $)=$ 1,101 dan $F_{\text {hitung }}$ (postest) $=1,227$ sedangkan $F_{\text {tabel }}$ (pretest dan postest) = 1,786. Maka uji homogenitas pretest kelas Eksperimen 1 dan kelas Eksperimen 2 diperoleh $F_{\text {hitung }}(1,101) \quad<F_{\text {tabel }}(1,786)$ dan data postest kelas Eksperimen 1 dan kelas Eksperimen 2 diperoleh $F_{\text {hitung }}(1,227)<F_{\text {tabel }}(1,786)$. Dengan demikian dapat disimpulkan pretest dan postest kelas Eksperimen 1 dan kelas Eksperimen 2 homogen.

Kemudian dilakukan pengujian hipotesis dengan menggunakan uji $t$. Setelah dilakukan pengujian data diperoleh $t_{\text {hitung }} 2,782>t_{\text {tabel }} 1,997$. Maka hipotesis diterima, yang berarti ada peningkatan kemampuan komunikasi matematika antara siswa yang diajar menggunakan model kooperatif tipe Think Pair Share (TPS) dengan Teams Games Tournament (TGT) kelas VIII MTs Laboratorium IAIN SU Medan 


\section{SIMPULAN DAN SARAN}

Berdasarkan analisa data pada penelitian ini maka penulis mengambil kesimpulan sebagai berikut : Dari pengujian hipotesis dengan menggunakan uji $t$ diperoleh $t_{\text {hitung }} 2,782>t_{\text {tabel }}$ 1,997. Dapat disimpulkan bahwa ada perbedaan peningkatan kemampuan komunikasi matematika antara siswa yang diajar menggunakan model kooperatif tipe Think Pair Share (TPS) dengan Teams Games Tournament (TGT) kelas VIII MTs Laboratorium IAIN SU Medan

Adapun menjadi saran dalam penelitian ini adalah :

1. Bagi guru matematika dapat menjadikan model pembelajaran Think Pair Share (TPS) sebagai salah satu alternatif dalam memilih model pembelajaran yang diharapkan dapat meningkatkan kemampuan komunikasi matematika siswa.

2. Kepada siswa, khususnya siswa MTs Laboratorium IAIN SU Medan disarankan untuk saling bekerja sama dalam diskusi kelompok dalam menjawab soal yang berhubungan dengan materi matematika sehingga dapat meningkatkan kemampuan komunikasi matematika.

3. Kepada peneliti lanjutan dapat mengadakan inovasi dari Think Pair Share (TPS) dan Teams Games Tournament (TGT) sebagai penelitian lanjutan studi perbandingan untuk mendapatkan hasil yang lebih baik yang dapat meningkatkan mutu pendidikan.

\section{DAFTAR PUSTAKA}

Istarani. (2012). 58 Model Pembelajaran Inovatif. Medan: Media Persada.

Lestari, E. K. (2015). Penelitian Pendidikan Matematika. Bandung: PT. Rafika Aditama.

Rusman. (2014). Model-Model Pembelajaran Mengembangkan Profesionalisme Guru. Jakarta: Rajawali Pers.

Salvin. (2009). Cooperative Learning (Teori, Riset, Praktik). Bandung.

Sudijono. (2011). Pengantar Evaluasi Pendidikan. Jakarta: Pt. Grafindo Persada.

Sudjana. (2005). Metode Statistika. Bandung: Tarsito.

Sugiono. (2013). Metode Penelitian Pendidikan Penedekatan Kuantitatif, Kualitatif, dan R\& D. Bandung: Alfabeta.

Trianto. (2009). Mendesain Model Pembelajaran Inovatif-Progresif, Konsep, Landasan dan Implementasinya pada Kurikulum Tingkat Satuan Pendidikan (KTSP) . Jakarta: Kencana. 